\title{
WASHINGTON HOTLINE
}

Carol C. Henderson

(202) 547-4440; ALA0025

Deputy Director, ALA Washington Office

This month there is good news on library funding (but action needed), an alert to an FCC proposal, and news of three of your colleagues who have testified before Congress in recent weeks.

HEA II-D funding. The House passed a funding bill for fiscal year 1988 with $\$ 5$ million for the new Higher Education Act title II-D College Library Technology and Cooperation Grants. HR 3058 also contains level funding for II-C research libraries ( $\$ 6$ million) and II-B training and research ( $\$ 1$ million), and an increase from $\$ 18$ to $\$ 20$ million for LSCA III interlibrary cooperation.

ACTION NEEDED: Constituents should thank Rep. John Porter (R-IL) for his leadership in requesting funds for II-D, and also Labor-HHS-Education Appropriations Subcommittee Chairman William Natcher (D-KY) and ranking minority member Silvio Conte (R-MA). The next step is for the Senate L-HHS-Ed Appropriations Subcommittee to meet soon after Labor Day. Letters, phone calls or mailgrams in support of funding for II-D and II-A, College Library Resources grants now targeted to the neediest libraries, should go immediately to Chairman Lawton Chiles (D-FL) and members Byrd (D-WV), Proxmire (D-WI), Hollings (D-SC), Burdick (D-ND), Inouye (D-HI), Harkin (D-IA), Bumpers (D$A R)$, Weicker (R-CT), Hatfield $(R-O R)$, Stevens (R-AK), Rudman (R-NH), Specter $(R-P A), M c C l u r e(R-I D)$, and Domenici (R-NM). Senate funding is not assured; contacts are needed.

FCC proposa1. The Federal Communications Commission has proposed to impose access charges for transmissions over value-added networks (VANs) such as Telenet, Tymnet, etc., beginning January 1. If approved, the effects on libraries would be as follows: For libraries with dial-up access to OCLC through CompuServe, an added $\$ 2.50$ per hour in telecommunications costs. For libraries using online databases though VANs or electronic mail over VANs, an added $\$ 4.47$ per hour. Comments to the FCC are due September 24.

ACTION NEEDED: Share the impact on your 1ibrary or system with the ALA Washington office as soon as possible, and then use it in letters to the FCC, Washington, DC 20054 (CC Docket 87-215, Amendments of Part 69 of the Commission's Rules Relating to Enhanced Service Providers), and to your Representative and Senators.

NTIS, sci/tech info. Harold Shi11, head librarian at West Virginia's Evansdale Library and new chair of the ACRL Legislation Committee and the ALA Legislation Assembly, testified July 14 before the House Science, Research, and Technology Subcommittee. The hearing focused on federal science and technology information resources policy, on possible policy mechanisms, and on proposals to privatize the National Technical Information Service (NTIS).

(cont'd on p. 470) 


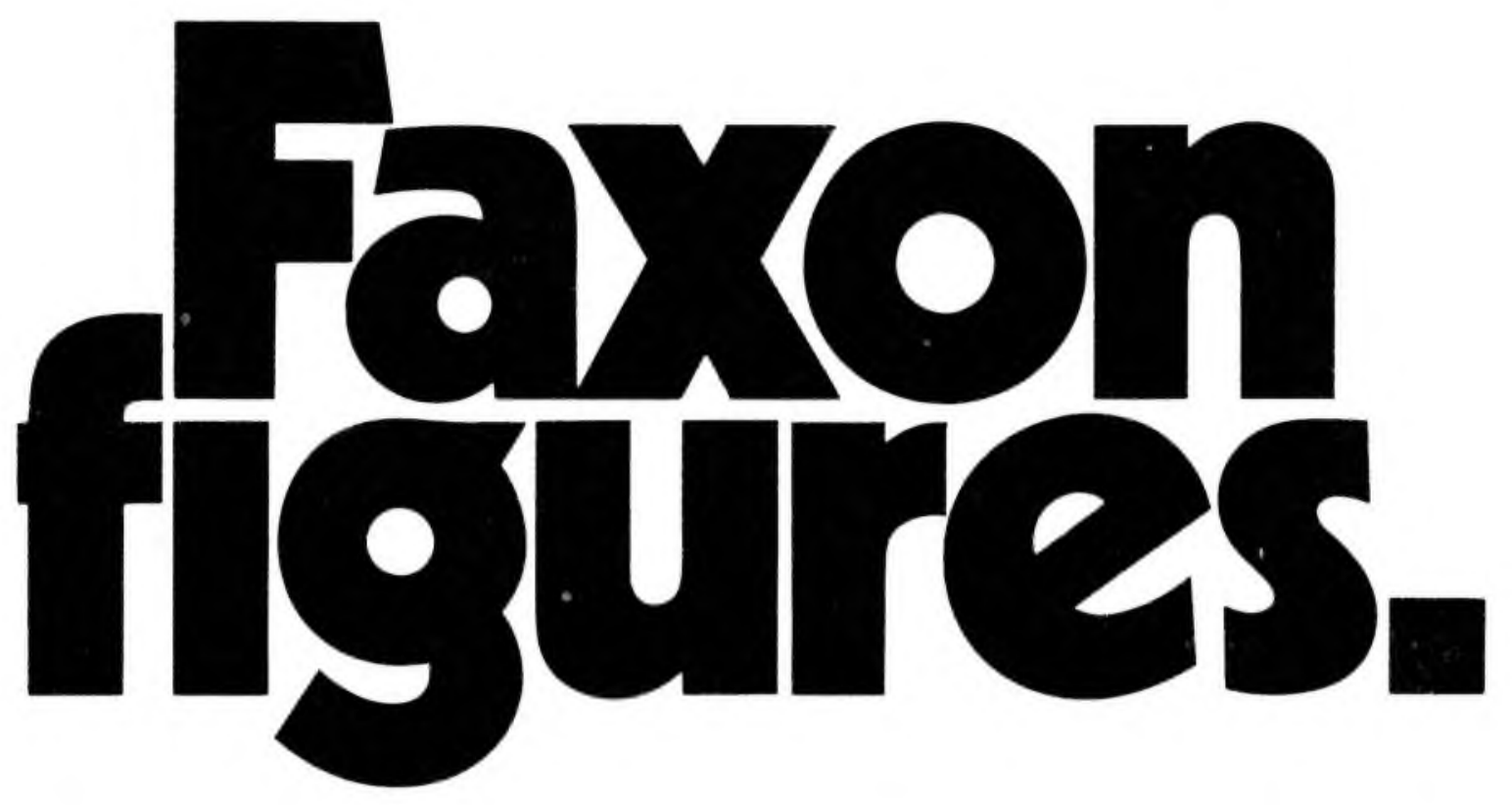

Productivity is a critical concern in today's library. That's why more and more decision makers are looking into Faxon. We can be the best source for all of your journal and continuation subscriptions. Our services enable you to devote your valuable personnel resources to other crucial library functions.

As a full service agent with access to more than 200,000 different periodicals, we can handle ordering, claiming, check-in, and routing. Our growing international network links you to other libraries, publishers, online systems, and networks.

If you can profit from improved productivity, a call to Faxon figures.

$1-800-225-6055$

or 1-617-329-3350 (collect)

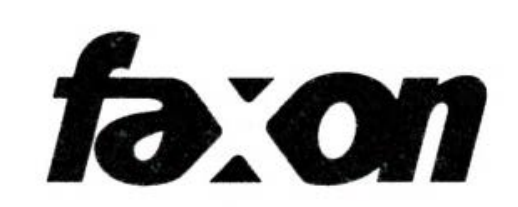

The Faxon Company 15 Southwest Park Westwood, MA 02090 
In wide-ranging testimony in response to the subcommittee's questions, Shill reiterated ALA's support for the depository library electronic pilot projects, and for essential NTIS functions being performed by a government agency, and suggested that the subcommittee look to the National Commission on Libraries and Information Science as a policy coordinating mechanism. Although not yet final, both the House and the Senate, in separate actions on different bills, have prohibited NTIS from contracting out activities not currently performed by outside contractors.

ERIC. The House Select Education Subcommittee, chaired by librarian Rep. Major Owens (D-NY), held on July 30 the first ever oversight hearing on the Educational Resources Information Center (ERIC) system. The Department of Education has proposed a redesign of ERIC. Rep. Owens concluded: "We must rally to save ERIC from a slow death, lest we squander a vital and irreplaceable resource. First and foremost, this means ensuring that if restructuring is to take place, it will enhance and not erode the capacity of the system to perform its critical functions."

ALA was represented at the hearing by Leslie Bjorncrantz, curriculum librarian and education bibliographer at Northwestern University Library, and an active member of ACRL's Education and Behavioral Sciences Section. She said ERIC has many strengths and provides a valuable service, listed specific examples of recent uses of the system, said ACCESS ERIC, a proposed new promotional and marketing unit, would be helpful, but her "main concern is that this vital new venture be funded adequately so that 1) the costs of establishing ACCESS ERIC do not drain funds from the basic ERIC system activities of acquiring and disseminating information in the field of education; and 2) the clearinghouses will be prepared to meet the increased demands placed on them by rising user expectations."

1990 Census. Rache1 VanWingen, government documents librarian at Georgetown University and GODORT member, testified for ALA at an August 7 hearing called on short notice by the Joint Economic Committee to examine the potential effects of the Office of Management and Budget's suprise proposal to cut one-third of the questions on the 1990 census. The data collection at issue involves statistics in areas such as housing, employment, energy, and transportation in the 1988 Decennial Census Dress Rehearsal.

In remarks Chairman Sen. Paul Sarbanes (D-MD) characterized as a "strong and thoughtful statement," VanWingen said: "As far as the library community is concerned, the planning for the 1990 Census was thorough, professional and fair. The Bureau held public hearings on subject content and products. Input from librarians and library users was solicited, and Census Staff members appeared at ALA conferences to keep us apprised of the planning stages."

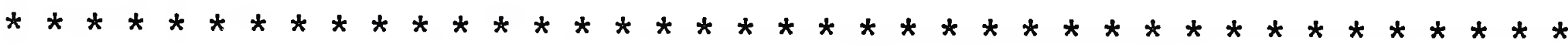

Output measures for academic and research libraries: Request for proposals

The Association of College and Research Libraries is soliciting proposals to prepare a manual of output measures for academic and research libraries. The proposed manual will assist academic and research librarians in measuring the impact, efficiency, and effectiveness of library activities. Proposals are due November 1, 1987. For a copy of the RFP contact: Mary E1len Davis, Program Officer, ACRL/ALA, $50 \mathrm{E}$. Huron Street, Chicago, IL 60611; (312) 944$6780, \times 287$. 